\title{
Revitalization and preservation of biodiversity. Focus on water bodies in the Cracow region
}

\author{
Aleksandra Wagner \\ AGH University of Science and Technology, Poland \\ Ahmad Gholami \\ Kharazmi University, Iran \\ Katharina Maletz \\ University of Graz, Austria \\ Ina K. Talmo \\ Norwegian University of Life Sciences, Ås, Norway
}

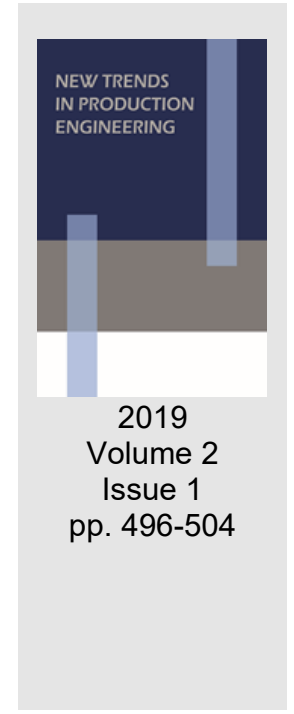

Date of submission to the Editor: 05/2019

Date of acceptance by the Editor: 08/2019

\section{INTRODUCTION}

The process of revitalization can be defined in many ways. The most common definition describes revitalization as "many-sided effort including revalorization, restoration, reconstruction, modernization, and actions aimed at revival of a building, district or a town devastated in various aspects, also economic and social" (Pawłowska and Swaryczewska 2002, Wilczkiewicz and WilkoszMamcarczyk, 2015). This definition emphasizes social and economic aspects, but seems to neglect environmental aspects, such as biodiversity. For example, in Warsaw the decline of bird population was observed in the Kępa Potocka Park after modernization (Popko, 2008).

This paper will focus on water bodies in Cracow (Kraków) and two neighboring communes. Most of the water bodies now have decorative and recreational functions. In the past most of these water bodies were fish ponds, one (Zabierzów) was formed after liquidation of a limestone quarry and one (Zalew Nowohucki) was made on the Dłubnia River, as a reservoir of water from industrial purposes. All these water experienced human neglect at certain point. Nowadays revitalization measures are taken. The paper presents preliminary results of the assessment of revitalization efforts and their possible effects on biodiversity, focussing on waterfowl. There is fear that removal of plants

\section{STUDY AREA AND METHODOLOGY}

The study was carried out in July 2018 and May 2019. Direct observation, analysis of maps as well as interviews with stakeholders and residents were applied as a method.

The area and perimeter were measured with the use of Google Maps. The water bodies were assessed in terms of the management of the area, type of vegetation and observed bird species. 
The maps of the studied water bodies are shown in Fig. 1 and 2.

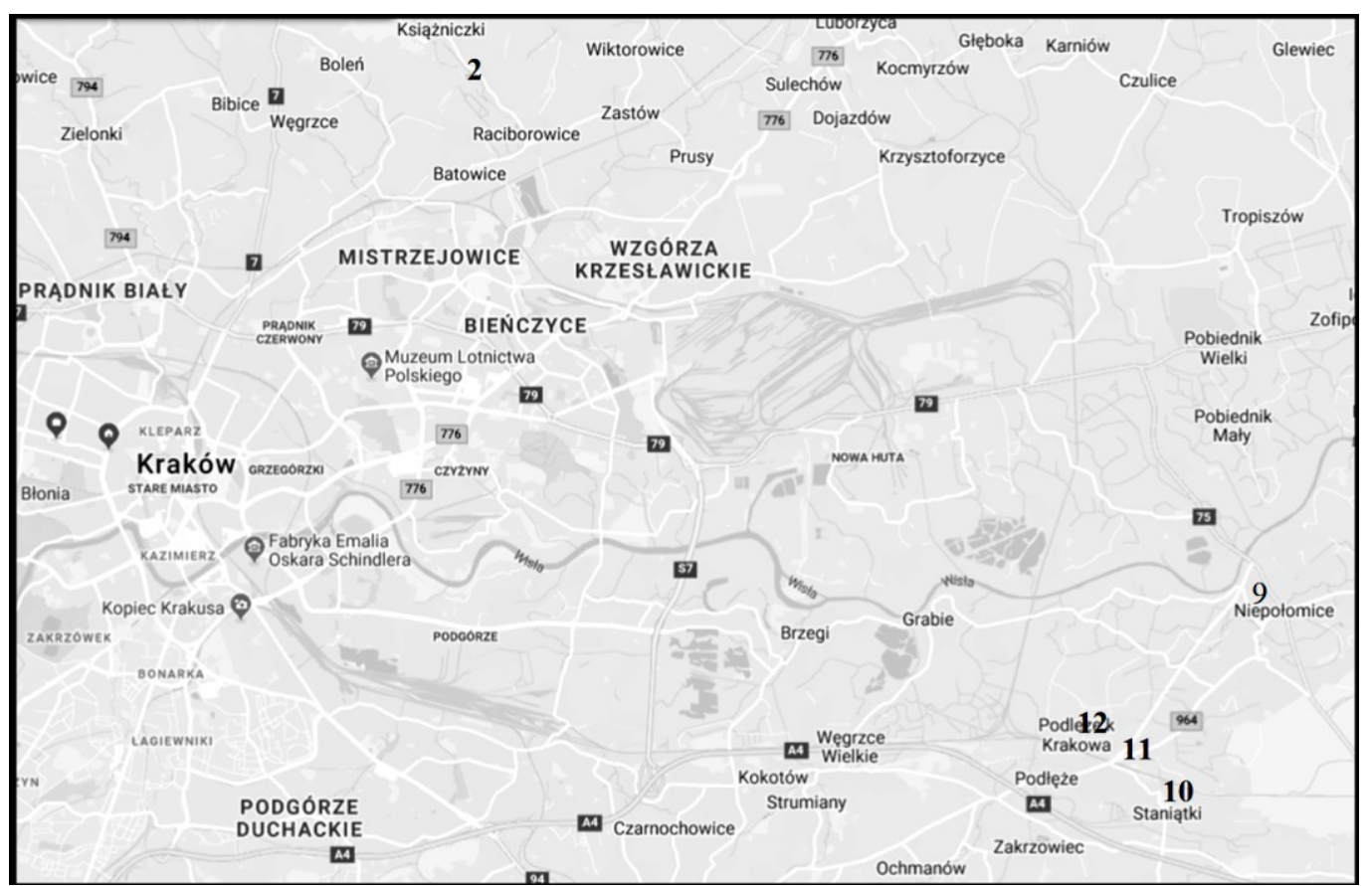

Fig. 1 The distribution of the studied water bodies in Cracow (Kraków) (1 and 2) and the commune of Niepołomice (10-12)

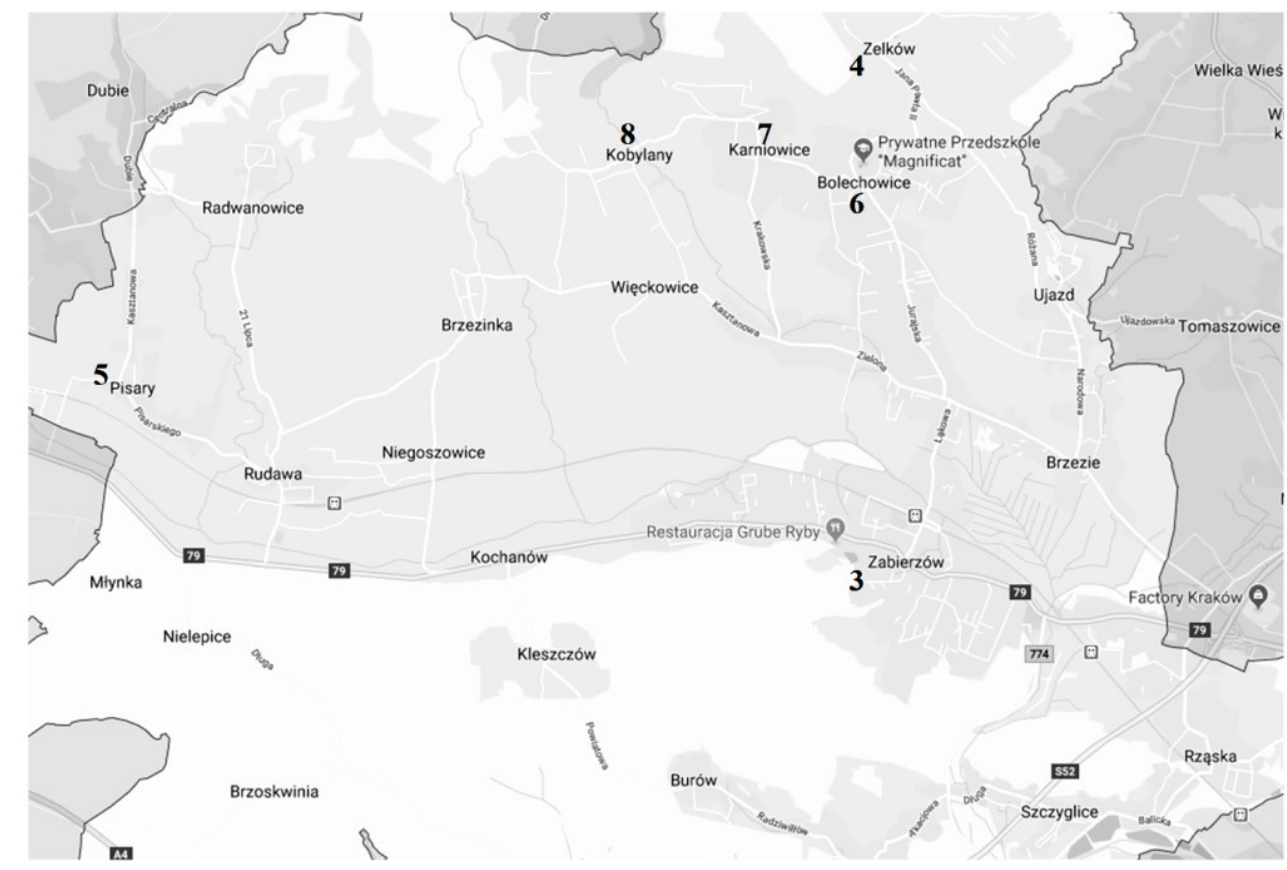

Fig. 2 The map of water bodies in Zabierzów

The following water bodies were studied (their area and perimeter are given in Table 1). 
Table 1 Characteristics of the water bodies examined in this paper (Kraków and its vicinity)

\begin{tabular}{|c|c|c|c|c|c|c|c|}
\hline \multirow{2}{*}{\multicolumn{2}{|c|}{$\begin{array}{l}\text { Water } \\
\text { Body }\end{array}$}} & \multirow{2}{*}{$\begin{array}{c}\text { Area, ha } \\
\text { Perimeter } \\
\text { m }\end{array}$} & \multicolumn{2}{|c|}{ Vegetation } & \multicolumn{2}{|c|}{ Bird species } & \multirow[b]{2}{*}{ Management } \\
\hline & & & $\begin{array}{l}\text { July } \\
2018\end{array}$ & $\begin{array}{l}\text { May } \\
2019\end{array}$ & $\begin{array}{l}\text { July } \\
2018\end{array}$ & $\begin{array}{l}\text { May } \\
2019\end{array}$ & \\
\hline \multicolumn{8}{|c|}{ Kraków } \\
\hline 1 & $\begin{array}{l}\text { Zalew } \\
\text { Nowohucki }\end{array}$ & $\begin{array}{l}7.64 \\
1.250\end{array}$ & $\begin{array}{l}\text { Most area } \\
\text { mowed, reed } \\
\text { bed left in } \\
\text { north-eastern } \\
\text { part. Vegetation } \\
\text { left on the islet } \\
\text { in the eastern } \\
\text { part }\end{array}$ & $\begin{array}{l}\text { No major } \\
\text { changes }\end{array}$ & 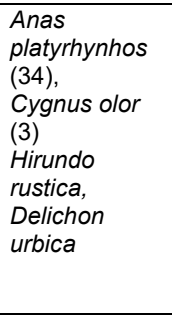 & $\begin{array}{l}\text { Anas } \\
\text { platyrhynhos } \\
(15) \\
\text { Hirundo } \\
\text { rustica (1) }\end{array}$ & $\begin{array}{l}\text { Revitalization has } \\
\text { been going on since } \\
2006 \text {. In September } \\
2018 \text { machines to } \\
\text { deliver grain for } \\
\text { birds were brought. } \\
\text { Nesting boxes put } \\
\text { on the trees. Main } \\
\text { activity is angling, } \\
\text { but small boats and } \\
\text { are used }\end{array}$ \\
\hline 2 & $\begin{array}{l}\text { Kaczeńcow } \\
\text { a Street }\end{array}$ & $\begin{array}{l}0.78 \\
372\end{array}$ & $\begin{array}{l}\text { Litoral } \\
\text { vegetation } \\
\text { moderately } \\
\text { rich. Typha } \\
\text { latifolia }\end{array}$ & $\begin{array}{l}\text { No major } \\
\text { changes }\end{array}$ & $\begin{array}{l}\text { Anas } \\
\text { platyrhynhos } \\
(46) \\
\text { Cygnus olor } \\
(1)\end{array}$ & $\begin{array}{l}\text { Anas } \\
\text { platyrhynhos } \\
\text { (4 males, } \\
2 \text { females - } \\
\text { one with } 7 \\
\text { and } 4 \\
\text { ducklings, } \\
\text { Gallinula } \\
\text { chloropus (1) }\end{array}$ & $\begin{array}{l}\text { Officially recognized } \\
\text { as ecological utility. } \\
\text { Littering is a } \\
\text { problem. }\end{array}$ \\
\hline \multicolumn{8}{|c|}{ Commune of Zabierzów } \\
\hline 3 & Zabierzów & $\begin{array}{l}0.94 \\
505\end{array}$ & $\begin{array}{l}\text { Typha only } \\
\text { occasionally, } \\
\text { steep shore } \\
\text { (former } \\
\text { limestone } \\
\text { quarry), ruderal } \\
\text { vegetation }\end{array}$ & $\begin{array}{l}\text { No major } \\
\text { changes, } \\
\text { grass } \\
\text { mowed }\end{array}$ & $\begin{array}{l}\text { Anas } \\
\text { platyrhynhos } \\
(8), \\
\text { Hirundo } \\
\text { rustica, } \\
\text { Delichon } \\
\text { urbica } \\
\end{array}$ & $\begin{array}{l}\text { Anas } \\
\text { platyrhynhos } \\
(2)\end{array}$ & $\begin{array}{l}\text { 30th May intensive } \\
\text { works were carried } \\
\text { out - new walking } \\
\text { paths, special } \\
\text { places for barbecue } \\
\text { and litterbins. }\end{array}$ \\
\hline 4 & Zelków & $\begin{array}{l}0.28 \\
219\end{array}$ & $\begin{array}{l}\text { Small amount } \\
\text { of Typha and } \\
\text { Iris } \\
\text { pseudeoacorus } \\
\text { Nuphar lutea, } \\
\text { Nymphea alba } \\
\text { cultivar with } \\
\text { pink flowers }\end{array}$ & $\begin{array}{l}\text { No major } \\
\text { changes } \\
\text { Nuphar } \\
\text { lutea and } \\
\text { Iris } \\
\text { pseudeoaco } \\
\text { rus are } \\
\text { flowering }\end{array}$ & $\begin{array}{l}\text { Anas } \\
\text { platyrhynhos } \\
(16) \\
\text { Hirundo } \\
\text { rustica }\end{array}$ & $\begin{array}{l}\text { No waterfowl } \\
\text { observed }\end{array}$ & $\begin{array}{l}\text { The fountain and an } \\
\text { islet in the middle of } \\
\text { the pond. The pond } \\
\text { embankment made } \\
\text { of wicker. }\end{array}$ \\
\hline 5 & Pisary & $\begin{array}{l}0.09 \\
110\end{array}$ & $\begin{array}{l}\text { No vegetation, } \\
\text { reconstruction } \\
\text { works }\end{array}$ & $\begin{array}{l}\text { Cattail on } \\
\text { the islet, } \\
\text { shore } \\
\text { mowed, } \\
\text { filamentous } \\
\text { algae }\end{array}$ & $\begin{array}{l}\text { No waterfowl } \\
\text { noticed }\end{array}$ & $\begin{array}{l}\text { Anas } \\
\text { platyrhynhos } \\
(2)\end{array}$ & $\begin{array}{l}\text { Effects of } \\
\text { renovation: } \\
\text { vegetation grows. } 7 \\
\text { nesting boxes put on } \\
\text { the trees }\end{array}$ \\
\hline 6 & $\begin{array}{l}\text { Bolechowic } \\
\text { e }\end{array}$ & $\begin{array}{l}0.08 \\
107\end{array}$ & $\begin{array}{l}\text { Park } \\
\text { vegetation, } \\
\text { Iris } \\
\text { pseudoacorus } \\
\text { Nuphar lutea } \\
\end{array}$ & $\begin{array}{l}\text { Iris } \\
\text { pseudoacor } \\
\text { us is } \\
\text { flowering }\end{array}$ & $\begin{array}{l}\text { Anas } \\
\text { platyrhynhos } \\
(16-\text { male } \\
\text { and female })\end{array}$ & $\begin{array}{l}\text { Anas } \\
\text { platyrhynhos } \\
(2 \text { males })\end{array}$ & $\begin{array}{l}\text { The waterbody } \\
\text { is in a park }\end{array}$ \\
\hline 7 & Karniowice & $\begin{array}{l}0.05 \\
66\end{array}$ & $\begin{array}{l}\text { No litoral } \\
\text { vegetation, } \\
\text { grass mowed } \\
\text { short }\end{array}$ & $\begin{array}{l}\text { Meadow } \\
\text { vegetation, } \\
\text { densely } \\
\text { grown } \\
\text { Quercus } \\
\text { robur, reed } \\
\text { outside the } \\
\text { pond } \\
\end{array}$ & $\begin{array}{l}\text { No waterfowl, } \\
\text { Hirundo } \\
\text { rustica }\end{array}$ & $\begin{array}{l}\text { Anas } \\
\text { platyrhynhos } \\
(2 \text { males, } 1 \\
\text { female })\end{array}$ & $\begin{array}{l}\text { Revitaliation carried } \\
\text { out in } 2018 \text {. } \\
\text { Playground built } \\
\text { nearby }\end{array}$ \\
\hline 8 & Kobylany & $\begin{array}{l}0.02 \\
53\end{array}$ & $\begin{array}{l}\text { Ornamental } \\
\text { plants grown } \\
\text { near the water } \\
\text { body }\end{array}$ & $\begin{array}{l}\text { No major } \\
\text { changes in } \\
\text { vegetation, } \\
\text { filamentous } \\
\text { algae }\end{array}$ & No waterfowl & No waterfowl & $\begin{array}{l}\text { A monument (stone) } \\
\text { erected nearby, } \\
\text { problems with litter }\end{array}$ \\
\hline \multicolumn{8}{|c|}{ Commune of Niepołomice } \\
\hline 9 & $\begin{array}{l}\text { Niepołomic } \\
\text { e - } \\
\text { Zamkowa }\end{array}$ & $\begin{array}{l}0.11 \\
154\end{array}$ & $\begin{array}{l}\text { Willow around } \\
\text { the edges }\end{array}$ & $\begin{array}{l}\text { Most litoral } \\
\text { vegetation } \\
\text { (willow) cut } \\
\text { Sedum } \\
\text { appeared } \\
\text { on the } \\
\text { slopes }\end{array}$ & $\begin{array}{l}\text { Anas } \\
\text { platyrhynhos } \\
(16)\end{array}$ & $\begin{array}{l}\text { Turdus } \\
\text { pilaris (3). } \\
\text { One forages } \\
\text { very close to } \\
\text { water table }\end{array}$ & $\begin{array}{l}\text { In } 2005 \text { wicker } \\
\text { embankment and } \\
\text { the islet made. In } \\
2010 \text { the islet } \\
\text { disappeared and the } \\
\text { embankment started } \\
\text { overgrowing }\end{array}$ \\
\hline 10 & $\begin{array}{l}\text { Staniątki - } \\
\text { Klasztorna }\end{array}$ & $\begin{array}{l}0,11 \\
124 \text { (bigger } \\
\text { pond) } \\
0,05 \\
87 \text { (smaller } \\
\text { pond) }\end{array}$ & $\begin{array}{l}\text { Dense } \\
\text { vegetation of } \\
\text { Glyceria and } \\
\text { Typha, } \\
\text { Potamogeton in } \\
\text { water }\end{array}$ & $\begin{array}{l}\text { Similar } \\
\text { vegetation, } \\
\text { Iris } \\
\text { pseudoacor } \\
\text { us }\end{array}$ & $\begin{array}{l}\text { Anas } \\
\text { platyrhynhos, } \\
\text { Gallinula } \\
\text { chloropus (1 } \\
\text { juvenile) }\end{array}$ & $\begin{array}{l}\text { No waterfowl } \\
\text { observed, } \\
\text { Hirundo } \\
\text { rustica }\end{array}$ & $\begin{array}{l}\text { In late } 1900 \text { s - one } \\
\text { pond, later on split } \\
\text { into two ponds, in } \\
\text { May } 2019 \\
\text { detergents noticed } \\
\text { in the stream } \\
\text { empowering the big } \\
\text { pond }\end{array}$ \\
\hline 11 & $\begin{array}{l}\text { Staniątki - } \\
\text { Piłsudskieg } \\
\text { o }\end{array}$ & $\begin{array}{l}0.29 \\
368\end{array}$ & $\begin{array}{l}\text { Dense } \\
\text { vegetation - } \\
\text { cattail (Typha } \\
\text { sp.) }\end{array}$ & $\begin{array}{l}\text { Dense } \\
\text { vegetation - } \\
\text { cattail } \\
\text { (Typha sp.) }\end{array}$ & $\begin{array}{l}\text { Anas } \\
\text { platyrhynchos } \\
\text {, Gallinula } \\
\text { chloropus (1) }\end{array}$ & $\begin{array}{l}\text { Anas } \\
\text { platyrhyncho } \\
\text { s, Gallinula } \\
\text { chloropus (1) }\end{array}$ & $\begin{array}{l}\text { No special } \\
\text { management. The } \\
\text { pond is difficult to } \\
\text { access. }\end{array}$ \\
\hline
\end{tabular}




\begin{tabular}{|c|c|c|c|c|c|c|c|}
\hline 12 & $\begin{array}{l}\text { Podłęże - } \\
\text { Stawowa }\end{array}$ & $\begin{array}{l}0.17 \\
182\end{array}$ & $\begin{array}{l}\text { Almost no } \\
\text { litoral } \\
\text { vegetation, } \\
\text { intensive } \\
\text { mowing }\end{array}$ & $\begin{array}{l}\text { No major } \\
\text { changes }\end{array}$ & No waterfowl & No waterfowl & $\begin{array}{l}\text { In July } 2018 \text { there } \\
\text { was a fountain, it } \\
\text { was not working in } \\
\text { May } 2019 . \text { The pond } \\
\text { is fenced }\end{array}$ \\
\hline
\end{tabular}

\section{In the city of Cracow (the city district of - Bieńczyce. Nowa Huta):}

- Zalew Nowohucki (1) - a water body formed on the Dłubnia River according to the project of A. Ścigalski, in $1957 \mathrm{r}$. It was designed as the water reservoir for industrial purposes as well as recreational object. At first the object was used for swimming, kayaking and other water sports. At the reservoir also picnics and concerts were held. Later on the water body was neglected. The only activity was fishing. At the beginning of $21^{\text {st }}$ century, due to the grants from the European Union the process of revitalization started (OrlewiczMusiał and Wagner, 2014). Later on the renovation was continued from the funds of the municipality of Cracow and the district of Bieńczyce (Rogozik, 2017).

- The pond of the Kaczeńcowa Street (2) - a pond on a former leat. With the surrounding area proclaimed Ecological Utility by the City Council of Cracow.

\section{In the commune of Zabierzów (the county of Cracow):}

- Zabierzów (3) - former limestone quarry (Fig. 3);

- Zelków (4) - a pond made to water cattle (Fig. 4);

- Pisary (5) - probably former fishing pond,

- Bolechowice (6) - one of two ponds (or a part of one pond separated by a dike)

- Karniowice (7) - probably a pond made to water cattle;

- Kobylany (8) - remains of former ponds situated around a manor. In the second half of $20^{\text {th }}$ century, after the nationalization, the ponds were neglected. Most of them were liquidated, only one remained, where rubbish was thrown

\section{In the commune of Niepołomice (the county of Wieliczka):}

- Niepołomice - Zamkowa (9) - former reservoir for firefighting, nowadays used for decorative purposes;

- Staniątki - Klasztorna (10) - former fish pond, nowadays two ponds separated by a dike

- Staniątki - Piłsudskiego (11) - former fish pond;

- Podłęże - Stawowa (12) former fish pond.

\section{RESULTS}

The results of the observations are shown in Table 1. Three species of birds living on water were observed: mallard (Anas platyrhynchos L.) - observed in 10 out of 12 water bodies, mute swan (Cygnus olor (Gmiel.)) - Zalew Nowohucki and Kaczeńcowa and moorhen (Gallinula chloropus (L.)) - observed in 3 water bodies (Kaczeńcowa in 2019, Staniątki-Klasztorna in 2018 and Staniątki- 
Piłsudskiego - in 2018 and 2019). In Staniątki-Klasztorna the observed individual was juvenile. The occurrence of moorhens was connected with rich litoral vegetation.

Apart from waterfowl there were other birds. The ones included in table 1 were swallows (Hirundo rustica L.) and house martins (Delichon urbica (L.)) - birds feeding on insects flying near the water body, as well as fieldfares (Turdus pilaris L.) - included, because one of them was observed foraging on the water table in Niepołomice. Pigeons and doves, especially urban form of rock pigeons Columba livia L., but also wood pigeon Columba palumbus L. and collar dove Streptopelia decaocto (Frivaldszky) were present at some water bodies, rock pigeons at many of them. They were not included into the table, because they are not directly related with water. The singing birds, such as members of crow family (Corvidae), especially jackdaws (Coloeus monedula (L.)) as well as many small species were observed, but not included into the table either, although the nesting boxes were seen at Zalew Nowohucki and Pisary.

Apart from birds amphibians (green frogs - Pelophylax esculentus comlex) were looked at. During the studies they were observed only in Staniątki-Klasztorna bigger pond.

Most of the water bodies were undergoing the process of revitalization. The most visible effects were observed in Zabierzów, where the work has been still going on (Fig. 3).

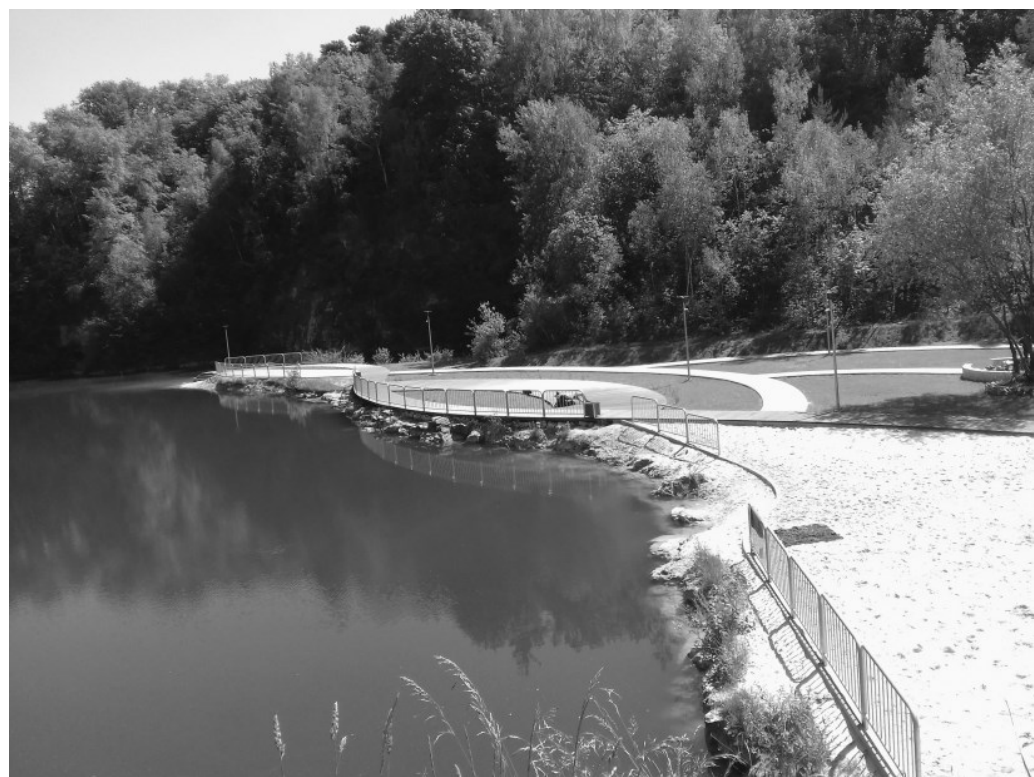

Source: Photo: A. Wagner

Fig. 3 The management of the water body in Zabierzów. 31 $1^{\text {st }}$ May 2019

\section{DISCUSSION}

The results included very short period of time - summer 2018 and spring 2019. Some of the water bodies have been studied before. They include Zalew Nowohucki and Kaczeńcowa (Wagner, 2012; Wagner 2017; Orlewicz-Musiał and Wagner, 2014; Wagner, 2017) as well as Staniątki (Wagner 2008, Wagner and Hasanagić 2014) and Niepołomice-Zamkowa (Wagner 2008). These studies show that more bird species were observed, but some of them only 
occasionally. For example, on Zalew Nowohucki the whooper swan (Cygnus cygnus (L.)) and grey heron (Ardea cinerea L.) were incidentally observed at Zalew Nowohucki. Black-headed gulls (Chroicocephalus ridibundus (L.)) were observed quite frequently in the past, but they did not nest there.

The most common waterfowl species nesting and/or foraging at the examined water bodies is mallard (Anas platyrhynchos). The fact that mallards foraged on most of the water bodies, shows that revitalization or renovation measures are not dangerous for them. Nevertheless ducklings were observed only in Kaczeńcowa, where litoral vegetation was relatively abundant. This also made it possible for moorhen to inhabit that area. The status of ecological utility is very helpful.

The Eurasian moorhen (Gallinula chloropus) is rarer than mallard. In Poland this species is protected by law, thus the areas where it lives should be preserved. Moorhens demand highly developed litoral vegetation (reed beds), so commonly practiced mowing and the removal of reed pose threat to this species (Zielińska, online). The problem is important in the case of the ponds in Staniątki. Moorhens were observed in both of the examined ponds, but the pond in the Piłsudski Street seems to be more "neglected". Nevertheless the "neglect" seems to be beneficial for moorhens. The ponds at the Klasztorna Street, situated in front of the Benedictine Convent and in Staniątki (of $13^{\text {th }}$ century) - Fig. 4. The pond (in 1990 s one, then two ponds were made has undergone revitalization. Although the area of water diminished, the reedmace (cattail) beds remained. Thus biodiversity could be preserved.

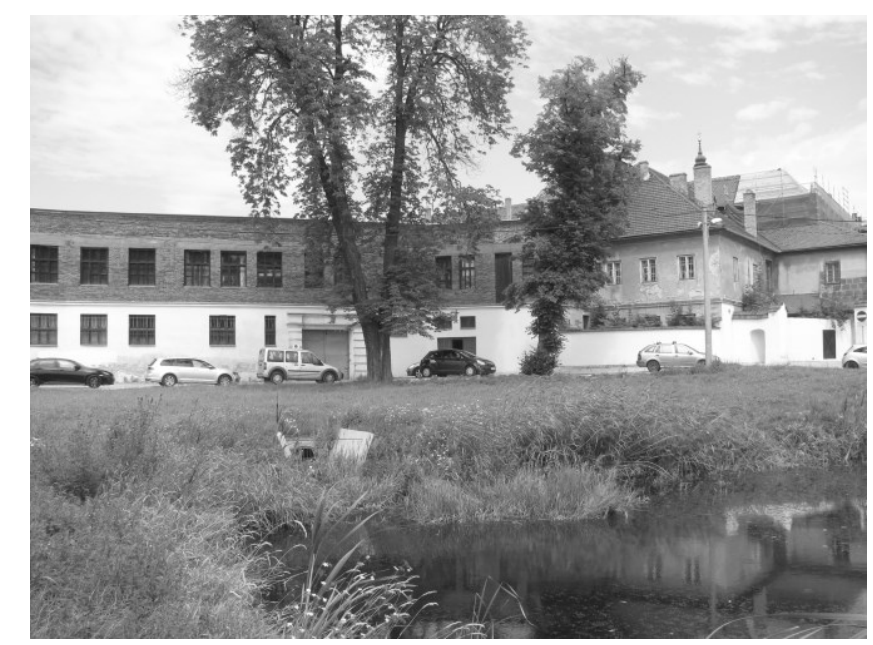

Fig. 4 The pond in Staniątki, the church and convent in the background.

Source: Photo: A. Wagner

Litoral vegetation is growing. 26 ${ }^{\text {th }}$ May 2019

The process of revitalization has been very intense in the community of Zabierzów. It was often connected with reducing the size of water bodies, which was most visible in Kobylany, where the pond was reduced to a size that makes this water body useless for most vertebrate species. The problem noticed in 2019 was large quantity of filamentous algae, indicating high eutrophication. The 
same problem occurred in Pisary, but the pond was bigger and ducks could forage there.

Most ponds had most or all of their tall litoral vegetation (Phragmites australis and Typha sp.) removed. Staff responsible for the maintenance of the ponds are afraid that reed and cattail would overgrow the pond, so removing the reed can save some work, nevertheless can discourage many species from visiting ponds.

In bigger ponds reed can be left in some part and removed in the other. A good solution is leaving islets in some parts of the water bodies. Birds nesting there are undisturbed. This has been done in Zalew Nowohucki. In Zabierzów steep limestone rocks prevent litoral vegetation from growing. Steep slopes also make bathing in the Zabierzów water body dangerous

Only in one water body the abundance of amphibians (frogs) was noticed (Staniątki-Klasztorna). An interview with a regular visitor indicated that some frogs occurred in Zabierzów. The same interview suggested that in that place grass snakes (Natrix natrix (L.)) occurred in the past, but have not been seen for a long time.

\section{CONCLUSION}

Intensive revitalization processes have been going on around most water bodies in the study area.

In some cases (Kobylany, Staniątki-Klasztorna) revitalization is connected with the diminishing of the area of the water body.

Some revitalization measures (removal of litoral vegetation) can diminish biodiversity by depriving the waterfowl of its habitat.

Mallards (the most commonly observed waterfowl species) are much more flexible in finding places to forage than moorhens, which need reedbeds. On the other hand the removal of riparian vegetation prevents small water bodies from disappearance.

Littering is a big problem in some locations. Litter bins should be placed in larger numbers, as well as more frequent cleaning is necessary.

In the former quarry of Zabierzów intense revitalization work has been going on, however the possibilities of recreation will not be fully used without the opportunity to swim. Swimming is forbidden there because of steep shore making the reservoir dangerous for people who cannot swim very well, because the areas deep water are found only one or two meters from the shore. The solution could be constructing special platforms for those who want to bathe, but this would be quite expensive.

Many water bodies in the study area are situated near the places of great historical value. This makes the possibility of combining natural and historical values of the objects. 


\section{ACKNOWLEDGEMENTS}

The authors wish to thank Ms. Aneta Mroczko-Porwisz of the Przedsiębiorstwo Usług Komunalnych Sp. z o.o. (Municipal Services) and Mr. Zdzisławow Mróz of the Division for Municipal Infrastructure of the commune of Zabierzów for providing us valuable information. The paper was financed by the AGH-UST grant 11.11.150.949. The study was done in the framework of IAESTE internship at AGH-UST in Cracow (Kraków)

\section{REFERENCES}

Orlewicz-Musiał, M. and Wagner, A. (2014). Przeobrażenia terenów zieleni miejskiej w związku z rozwojem infrastruktury sportowo-rekreacyjnej na przykładzie dzielnic Nowej Huty w Krakowie. In: M. Kosmala, ed. Kierunki zmian terenów zieleni w miastach, Toruń, Polskie Zrzeszenie Inżynierów i Techników Sanitarnych. Oddział Toruń, pp. 241-252.

Pawłowska, K. and Swaryczewska, M. (2002). Ochrona dziedzictwa kulturowego. Zarządzanie i partycypacja społeczna. Kraków: UJ.

Popko, J. (2008). Skutki przyrodnicze modernizacji parku Kępa Potocka w Warszawie. Turystyka i Rekreacja, 4, pp. 29-36.

Rogozik, M. (2017). Odnowienie otoczenia Zalewu Nowohuckiego coraz bliżej. Są już pierwsze ustalenia. Dziennik Polski, 24. Available at: https://dziennikpolski24.pl/odnowienie-otoczenia-zalewu-nowohuckiego-corazblizej-sa-juz-pierwsze-ustalenia/ar/11720292 [Accessed 2 Jun. 2019].

Uchwała nr XXXI/405/07 Rady Miasta Krakowa z dnia 19 grudnia 2007 r. w sprawie ustanowienia użytku ekologicznego "Staw przy Kaczeńcowej" [Resolution no. XXXI/405/07 of the City Council of Cracow of $19^{\text {th }}$ December 2007 on establishing an ecological utility "The Pond of the Kaczeńcowa Street". Available at: http://www.bip.krakow.pl/?dok_id=167\&sub_dok_id=167\&sub=uchwala\&query=i d\%3D17225\%26amp\%3Btyp\%3Du [Accessed 2 June 2019].

Wagner, A. (2008). The role of former fish ponds in environmental management - focus on the commune of Niepołomice, near Krakow (Poland). In: E. Kamler, K. Dabrowski, ed., Aquaculture Europe 2008: resource management - natural, human and material resources for the sustainable development of aquaculture +CD-ROM. Special Publication/European Aquaculture Society, pp. 679-680.

Wagner, A. (2012). Management of the industrial area of Nowa Huta (Kraków, Poland), focus on water bodies. Polish Journal of Environmental Studies, 21(5A), pp. 435439.

Wagner, A. (2017). Charakterystyka awifauny wybranych zbiorników wodnych na terenie Krakowa. In: M. Kosmala, ed., Dzika przyroda w mieście, Toruń, Polskie Zrzeszenie Inżynierów i Techników Sanitarnych. Oddział Oddział Toruń, pp. 93107.

Wagner, A., Hasanagić, D. (2014). Comparative analysis of selected water bodies in Cracow and vicinity in terms of their revitalisation. In: J. Skowronek, ed., Innowacyjne rozwiązania rewitalizacji terenów zdegradowanych. Katowice: Instytut Ekologii Terenów Uprzemysłowionych; Centrum Badań i Dozoru Górnictwa Podziemnego Sp. z o.o., pp. 139-152.

Wilczkiewicz, M. and Wilkosz-Mamcarczyk, M. (2015). Revitalization - definition, genesis, examples. Geomatics, Landmanagement and Landscape, 2, pp. 71-79. Available at: https://gll.urk.edu.pl/zasoby/74/Geomatics_2015_207_Wilczkiewicz_Wilkosz-Mamcarczyki.pdf [Accessed 2 Jun. 2019].

Zielińska, M. Poradniki ochrony siedlisk i gatunków. Ptaki (część I). Galinula chloropus [online]. Available at https://natura2000.gdos.gov.pl/files/artykuly/52989/a123_Kokoszka.pdf [Accessed 5 June 2019]. 


\section{Abstract.}

The studies included 2 water bodies in Cracow (Kraków), 6 water bodies in the commune of Zabierzów (Cracow County) and 4 in the commune of Niepołomice (Wieliczka County). The studies were carried out in June 2018 and May 2019. The ways on management of the water bodies were compared. Problems related to revitalization were identified. One of these problems is the preservation of biodiversity. In some cases revitalization reduces biodiversity. This can happen due to the liquidation or limitation of the reed bed zone. Such a situation was observed in the water bodied of Zelków and Karniowice (com. Zabierzów). Both have ornamental functions now. Removal of most of reed does not disturb mallards (Anas platyrhynchos), but makes it impossible to nest for other birds such as moorhen (Galinula chloropus). Moorhens were observed in two former fish ponds in Staniątki (com. Niepołomice) and in the pond of the Kaczeńcowa street. In one of them revitalization caused the diminishing of the water area, but did not change the character of the water body. Bird species were recorded at water bodies.

Keywords: ponds, revitalization, birds, biodiversity loss 